\title{
Intestinal microsporidiosis among HIV/ AIDS patients receiving antiretroviral therapy in Sana'a city, Yemen: first report on prevalence and predictors
}

Kwkab A. R. Al-Brhami ${ }^{1}$, Rashad Abdul-Ghani ${ }^{1,2^{*}}$ (D) and Salah A. Al-Qobati ${ }^{1}$

\begin{abstract}
Background: Intestinal microsporidiosis is an opportunistic infection associated with persistent diarrhea among HIV/ AIDS patients. In Yemen, however, its epidemiology is unknown. Therefore, this study determined its prevalence and predictors among HIV/AIDS patients receiving antiretroviral therapy (ART) in Sana'a city, the capital of Yemen.

Methods: This cross-sectional study included 402 patients receiving ART at Al-Jomhori Educational Hospital in Sana'a from November 2019 to December 2020. Data about demographics, clinical characteristics and risk factors were collected using a pre-designed questionnaire. Stool samples were collected and examined for microsporidian spores using the Gram-chromotrope Kinyoun staining. Blood samples were also collected and used for CD4 cell counting by flow cytometry. Univariate analysis was used to test the association of patients' characteristics and risk factors with intestinal microsporidiosis. Multivariable logistic regression was then used to identify the independent predictors of infection. Statistical significance was considered at $P$-values $<0.05$.
\end{abstract}

Results: Intestinal microsporidiosis was prevalent among 14.2\% (57/402) of HIV/AIDS patients and was significantly associated with diarrhea (OR 3.4, 95\% Cl 1.7-6.6; $P=0.001)$. The significant independent predictors of infection were $<200 \mathrm{CD} 4$ cells/ $\mu$ l (AOR 3.2, 95\% Cl 1.5-6.9; $P=0.003)$, not washing hands after contacting soil (AOR $2.5,95 \% \mathrm{Cl}$ $1.1-5.4 ; P=0.026$ ) and before eating (AOR 3.1,95\% Cl 1.5-6.4; $P=0.003$ ), eating unwashed raw produce (AOR 2.5, 95\% $\mathrm{Cl} 1.2-5.3 ; P=0.017$ ) and absence of indoor latrines (AOR 6.2, 95\% Cl 1.5-25.9; $P=0.012$ ).

Conclusions: The prevalence of intestinal microsporidiosis among HIV/AIDS patients in Sana'a is high and comparable to that reported from several other countries, being prevalent among approximately $14.0 \%$ of patients and significantly associated with diarrhea. It could be predicted among patients who have $<200$ CD4 cells/ $/$ l, have poor hand hygiene after contacting soil and before eating, usually eat unwashed raw produce, or do not possess indoor latrines. Large-scale studies on its epidemiology and predictors among HIV/AIDS patients across the country are warranted.

Keywords: Intestinal microsporidiosis, HIV/AIDS, Immunodeficiency, Prevalence, Predictors, Yemen

*Correspondence: rashadqb@yahoo.com

${ }^{1}$ Department of Medical Parasitology, Faculty of Medicine and Health

Sciences, Sana'a University, Sana'a, Yemen

Full list of author information is available at the end of the article

\section{Introduction}

Microsporidia are a group of unicellular, spore-forming parasites closely related to fungi that infect a wide spectrum of invertebrate and vertebrate hosts $[1,2]$. Human microsporidiosis was first reported in the late 1920s as reviewed by Weiss et al. [3], but human infections have 
been rarely reported before the discovery of the human immunodeficiency virus (HIV)/acquired immunodeficiency syndrome (AIDS) [4]. Since the AIDS pandemic in the early 1980s, microsporidia have emerged as important opportunistic parasites affecting immunocompetent individuals and immunocompromized patients, particularly AIDS patients, in developed and developing countries $[3,5]$. The most frequent causative agents of intestinal microsporidiosis in immunocompromized patients are Enterocytozoon bieneusi and Encephalitozoon intestinalis [6]. Humans acquire infection with microsporidia through several routes, including the ingestion or inhalation of spores besides direct and indirect zoonotic transmission [5, 7]. Vertical transmission has been reported in experimental animals, but no congenitally transmitted cases have been confirmed in humans [8]. Although intestinal microsporidiosis is usually asymptomatic or self-limiting in immunocompetent individuals, it can be severe and life-threatening in immunocompromized patients, particularly AIDS patients having a cluster of differentiation 4 (CD4+) T cells (also known as CD4 cells) of $<100$ cells $/ \mu$ l of blood [9]. Such patients are prone to develop chronic and debilitating diarrhea and other gastrointestinal manifestations, fever, weight loss and malabsorption syndrome [10].

HIV is a retrovirus that destroys activated CD4 cells, which play a major role in the regulation of humoral and cell-mediated immune responses, leading to infection with opportunistic pathogens that usually appear when the CD4 cell count declines below 200 cells per $\mu \mathrm{l}$ of blood as in AIDS patients [11]. By 2016, 36.7 million people have been estimated to be living with HIV worldwide, 1.8 million people became newly infected with the virus and 1.0 million people lost their lives because of AIDS [12]. In Yemen, the first HIV case was detected in 1987, and the National AIDS Control Program (NACP) was then established within the organogram of the Ministry of Public Health and Population to monitor and control HIV/AIDS in the country by providing counseling, testing and antiretroviral therapy (ART) services [13]. According to the NACP, a low HIV prevalence of $0.2 \%$ was estimated in 2011 in the country [14]. In 2016, 9900 people living with HIV have been estimated in the general population in the country despite reporting only 2701 cases [15].

Different laboratory techniques have been used to identify microsporidian spores in various clinical specimens, including light and fluorescence microscopy, transmission electron microscopy (TEM) as well as immunological and molecular techniques [16]. TEM is the gold standard technique to identify the specific species; however, it is time-consuming, expensive and cannot be performed on a large number of samples [17].
Polymerase chain reaction (PCR)-based techniques have improved the sensitivity and specificity of detection to the species level [16]. However, such techniques are not used routinely because they are time-consuming, laborintensive and costly in addition to the difficulty in isolating the nucleic acids from the spores and the presence of PCR inhibitors in stool samples $[6,18]$. Therefore, intestinal microsporidiosis is commonly diagnosed by the microscopical detection of spores in stool smears stained with Weber's modified trichrome (WMT) technique [3, 19-21]. Several modifications have been developed, with Gram-chromotrope staining being the much-improved differential technique for identifying the microsporidian spores [22, 23]. Gram-chromotrope Kinyoun (GCK) staining technique was later developed as a modification of the Gram-chromotrope technique with high specificity and sensitivity for identifying microsporidian spores [24].

On a global scale, the prevalence of intestinal microsporidiosis in HIV-infected patients varies considerably across countries and ranges from below $1.0 \%$ to over $80.0 \%$, predominantly in Southeast Asia, Middle East, Europe, Africa and Latin America [25]. It has been reported among $10-50 \%$ of HIV-infected patients with chronic diarrhea [25, 26]. In non-HIV-infected individuals, most infections occur in children, the elderly, travelers and organ transplant recipients [3]. In Yemen, one of the least-developed countries, the epidemiology of intestinal microsporidiosis is unknown. With the lack of published studies on its epidemiology among HIV/AIDS patients in the country, this study aimed to determine the prevalence of intestinal microsporidiosis, to identify its predictors and to assess its association with certain clinical manifestations among HIV/AIDS patients in Sana'a city.

\section{Methods}

\section{Study design and area}

This hospital-based, cross-sectional study was conducted in the ART clinic of the NACP at Al-Jomhori Educational Hospital in Sana'a city in the period from November 2019 to December 2020. Sana'a is located at the coordinates of $15^{\circ} 20^{\prime} 54^{\prime \prime} \mathrm{N}$ and $44^{\circ} 12^{\prime} 23 \mathrm{E}$ in north of Yemen. It has an estimated population of over 2.5 million people [27]. It is noteworthy that only one ART clinic offers treatment services to HIV/AIDS patients in the city.

\section{Study population}

HIV/AIDS patients receiving ART in the clinic of the NACP in Sana'a were recruited for this study irrespective of their gender or age. Patients were included if confirmed positive for HIV by enzyme-linked immunosorbent assay (ELISA) or PCR. Patients with other immunocompromizing conditions, such as cancer patients 
undergoing chemotherapy, organ transplant recipients, or hemodialysis patients, and those who refused to give written informed consent to participate were excluded.

\section{Sample size and sampling strategy}

The minimum sample size required was calculated to be 384 using EpiInfo software, version 2.3.1 (Centers for Disease Control and Prevention, Atlanta, USA). Because of the lack of previous studies on intestinal microsporidiosis among this population category, the calculation was based on the following parameters: an expected prevalence of $50.0 \%$, a confidence level of $95.0 \%$ and a precision of $5.0 \%$. However, 402 patients were included in this study by simple random sampling from the HIV/AIDS patients registered in the ART clinic of the NACP.

\section{Data collection}

Data about demographics, clinical characteristics and potential risk factors associated with intestinal microsporidiosis were collected using a pre-designed, structured questionnaire through face-to-face interviews. Patients were considered diarrheic if they had reported: the passage of three or more loose or liquid stools per day or more frequent passage than is normal for the individual according to WHO criteria [28], either on admission or one month before sample collection.

\section{Sample collection}

Fresh stool samples were collected into clean, dry, leakproof and pre-labeled containers and were preserved in $10 \%$ formalin until examined. In addition, about $3 \mathrm{ml}$ of blood samples were collected by aseptic venipuncture into pre-labeled tubes with ethylenediaminetetraacetic acid (EDTA) for CD4 cell counting.

\section{Detection of microsporidian spores}

Stool specimens were processed and examined at the Parasitology Laboratory at the Faculty of Medicine and Health Sciences, Sana'a University. Thin smears were prepared from unconcentrated stool [29] on pre-labeled glass slides, which were then thoroughly dried, fixed with absolute methanol and left to air-dry. The dried smears were stained with the GCK technique [24]. The stained smears were examined for microsporidian spores under the oil-immersion objective lens of a light microscope. The criteria used to identify the microsporidian spores were the detection of pinkish-blue ovoid structures with blue walls and encircled with deeply blue belt-like structures against a pale pink background [24]. At least 100 oil-immersion fields were examined before recoding the result as being negative for microsporidian spores.

\section{CD4 cell counting}

Twenty-five microliters of EDTA-anticoagulated blood were incubated with specific monoclonal antibodies labeled with a fluorescent dye. Blood was then used to count CD4 cells by flow cytometry using Pima ${ }^{\mathrm{TM}}$ analyzer (Alere Technologies $\mathrm{GmbH}$, Jena, Germany) as per the instructions of the manufacturer.

\section{Data analysis}

Data were analyzed using the IBM SPSS Statistics for Windows, Version 22.0 (IBM Corp., Armonk, NY, USA). Categorical variables were expressed as frequencies and proportions, while continuous variables were expressed as median \pm interquartile range (IQR) for non-normally distributed data. The prevalence of intestinal microsporidiosis was reported with its corresponding 95.0\% confidence interval (CI). Pearson's chi-square or Fisher's exact test, whichever suitable, was used to test the association of the independent variables (demographics, clinical characteristics and risk factors) with intestinal microsporidiosis as the dependent outcome in a univariate analysis. The odds ratios (ORs) and 95.0\% CIs for the association of the independent variables with intestinal microsporidiosis were reported. A multivariable logistic regression analysis of the significant predictors in the univariate analysis was then used to identify the independent predictors of intestinal microsporidiosis together with their adjusted ORs (AORs) and $95.0 \%$ CIs. $P$-values $<0.05$ were considered statistically significant.

\section{Results}

\section{Demographics of HIV/AIDS patients}

Table 1 shows that the majority of HIV/AIDS patients in Sana'a city were males (77.9\%), aged less than 40 years (64.9\%) with a median age of $37.0 \pm 15.0$ years (range: $5-80)$, urban residents $(55.8 \%)$ and living within households of 5 members or more $(60.4 \%)$ with a median household size of $7 \pm 5$ members. Approximately onethird of patients had primary education followed by those illiterate and who had secondary education $(27.3 \%$ and $20.7 \%$, respectively). More than half of patients were unemployed (56.2\%). Day workers represented $18.7 \%$ of patients, while public service employees represented the least frequent category of patients (6.3\%).

\section{Clinical characteristics of HIV/AIDS patients}

Table 2 shows that $22.7 \%$ of HIV/AIDS patients had CD4 cell counts of $<200$ cells $/ \mu \mathrm{l}$, with a median count of $355 \pm 288$ cells $/ \mu$ l. The clinical manifestations reported by 
Table 1 Demographics of HIV/AIDS patients receiving ART in the clinic of NACP at Al-Jomhori Educational Hospital in Sana'a, Yemen (2019-2020)

\begin{tabular}{|c|c|c|}
\hline Characteristics & $n$ & $(\%)$ \\
\hline \multicolumn{3}{|l|}{ Gender } \\
\hline Male & 313 & (77.9) \\
\hline Female & 89 & $(22.1)$ \\
\hline \multicolumn{3}{|l|}{ Age (years) } \\
\hline$<40$ & 261 & $(64.9)$ \\
\hline$\geq 40$ & 141 & $(35.1)$ \\
\hline \multicolumn{3}{|l|}{ Median \pm IQR: $37.0 \pm 15.0$} \\
\hline \multicolumn{3}{|l|}{ Range 5-80 } \\
\hline \multicolumn{3}{|l|}{ Residence $^{\mathrm{a}}$} \\
\hline Rural & 176 & $(44.2)$ \\
\hline Urban & 222 & $(55.8)$ \\
\hline \multicolumn{3}{|l|}{ Household size (members) } \\
\hline$<5$ & 159 & (39.6) \\
\hline$\leq 5$ & 243 & $(60.4)$ \\
\hline \multicolumn{3}{|l|}{ Median \pm IQR: $7 \pm 5$} \\
\hline \multicolumn{3}{|l|}{ Educational level $^{b}$} \\
\hline Illiterate & 99 & $(27.3)$ \\
\hline Informal education & 10 & $(2.8)$ \\
\hline Primary education & 134 & (36.9) \\
\hline Secondary education & 75 & $(20.7)$ \\
\hline University and above & 45 & $(12.4)$ \\
\hline \multicolumn{3}{|l|}{ Occupationc } \\
\hline Unemployed & 222 & $(56.2)$ \\
\hline Public service employee & 25 & $(6.3)$ \\
\hline Private sector employee & 40 & $(10.1)$ \\
\hline Day worker & 74 & $(18.7)$ \\
\hline Self-employed & 34 & (8.6) \\
\hline
\end{tabular}

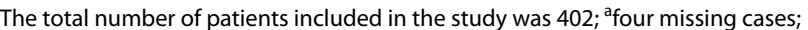
b39 missing cases; ${ }^{\mathrm{C}} 7$ missing cases

HIV human immunodeficiency virus, AIDS acquired immunodeficiency syndrome, ART antiretroviral therapy, NACP National AIDS Control Program, IQR interquartile range

patients were abdominal pain (32.8\%), diarrhea (12.9\%), nausea (22.6\%) and vomiting (9.5\%).

\section{Prevalence of intestinal microsporidiosis among HIV/AIDS patients}

Out of 402 HIV/AIDS patients, 57 (14.2\%; 95\% CI 11.018.1) were positive for intestinal microsporidiosis.

\section{Association of intestinal microsporidiosis with demographics and clinical characteristics of HIV/AIDS patients}

There was no statistically significant association between intestinal microsporidiosis and gender, age, residence, household size, literacy status, or employment status of
Table 2 Clinical characteristics of HIV/AIDS patients receiving ART in the clinic of NACP at Al-Jomhori Educational Hospital in Sana'a, Yemen (2019-2020)

\begin{tabular}{|c|c|c|}
\hline Characteristics & $n$ & $(\%)$ \\
\hline \multicolumn{3}{|c|}{ CD4 cell count $(/ \mu l)^{\mathrm{a}}$} \\
\hline$<200$ & 90 & $(22.7)$ \\
\hline$\geq 200$ & 306 & (77.3) \\
\hline \multicolumn{3}{|c|}{ Median \pm IQR: $355 \pm 288$} \\
\hline \multicolumn{3}{|l|}{ Diarrhea } \\
\hline Yes & 52 & $(12.9)$ \\
\hline No & 350 & $(87.1)$ \\
\hline \multicolumn{3}{|l|}{ Nausea } \\
\hline Yes & 91 & $(22.6)$ \\
\hline No & 311 & $(77.4)$ \\
\hline \multicolumn{3}{|l|}{ Vomiting } \\
\hline Yes & 38 & $(9.5)$ \\
\hline No & 364 & $(90.5)$ \\
\hline \multicolumn{3}{|l|}{ Abdominal pain } \\
\hline Yes & 132 & (32.8) \\
\hline No & 270 & $(67.2)$ \\
\hline
\end{tabular}

HIV/AIDS patients in Sana'a city. On the other hand, intestinal microsporidiosis was significantly higher among HIV/AIDS patients having diarrhea (OR 3.4, 95\% CI 1.7-6.6; $P=0.001$ ) but was not significantly associated with other gastrointestinal conditions (Table 3 ).

\section{Predictors of intestinal microsporidiosis among HIV/AIDS patients}

Having<200 CD4 cells/ $\mu$ l (OR 2.7, 95\% CI 1.5-5.0; $P=0.001)$, not washing hands after contact with soil (OR 3.1, 95\% CI 1.5-6.4; $P=0.002$ ), not washing hands before eating (OR 3.7, 95\% CI 2.0-6.6; $P<0.001$ ), eating unwashed raw produce (OR 2.1, 95\% CI 1.2-3.7; $P=0.015$ ) and absence of indoor latrines (OR 13.5, 95\% CI 4.8-38.3; $P<0.001)$ were significantly associated with intestinal microsporidiosis among HIV/AIDS patients. In contrast, there was no statistically significant association between intestinal microsporidiosis and the source of drinking water, bathing and/or swimming outdoors, presence of animals in the house, or indiscriminate defecation (Table 4).

\section{Independent predictors of intestinal microsporidiosis among HIV/AIDS patients}

Multivariable logistic regression analysis showed that having <200 CD4 cells/ $\mu$ l (AOR 3.2, 95\% CI 1.5-6.9; $P=0.003)$, not washing hands after contact with 
Table 3 Association of intestinal microsporidiosis with demographics and clinical characteristics of HIV/AIDS patients receiving ART in the clinic of NACP at Al-Jomhori Educational Hospital in Sana'a, Yemen (2019-2020)

\begin{tabular}{|c|c|c|c|c|}
\hline \multirow[t]{2}{*}{ Variable } & \multirow[t]{2}{*}{$N$} & \multicolumn{2}{|c|}{$\begin{array}{l}\text { Intestinal } \\
\text { microsporidiosis }\end{array}$} & \multirow[t]{2}{*}{$P$-value } \\
\hline & & $n(\%)$ & OR $(95 \% \mathrm{Cl})$ & \\
\hline \multicolumn{5}{|l|}{ Gender } \\
\hline Male & 313 & $41(13.1)$ & Reference & 0.301 \\
\hline Female & 89 & $16(18.0)$ & $1.5(0.8-2.7)$ & \\
\hline \multicolumn{5}{|l|}{ Age (years) } \\
\hline$<40$ & 261 & $39(14.9)$ & $0.8(0.5-1.5)$ & 0.653 \\
\hline$\geq 40$ & 141 & $18(12.8)$ & Reference & \\
\hline \multicolumn{5}{|l|}{ Residence } \\
\hline Rural & 176 & $30(17.0)$ & $1.5(0.8-2.6)$ & 0.195 \\
\hline Urban & 222 & $27(12.2)$ & Reference & \\
\hline \multicolumn{5}{|c|}{ Household size (members) } \\
\hline$<5$ & 159 & $16(10.1)$ & Reference & 0.059 \\
\hline$\geq 5$ & 243 & $41(16.9)$ & $1.8(1.0-3.4)$ & \\
\hline \multicolumn{5}{|l|}{ Literacy status } \\
\hline Illiterate & 99 & $17(17.2)$ & $1.3(0.7-2.4)$ & 0.508 \\
\hline Literate & 264 & $37(14.0)$ & Reference & \\
\hline \multicolumn{5}{|c|}{ Employment status } \\
\hline Unemployed & 222 & $36(16.2)$ & $1.5(0.8-2.7)$ & 0.195 \\
\hline Employed & 173 & $20(11.6)$ & Reference & \\
\hline \multicolumn{5}{|l|}{ Diarrhea } \\
\hline Yes & 52 & $16(30.8)$ & $3.4(1.7-6.6)$ & 0.001 \\
\hline No & 350 & $41(11.7)$ & Reference & \\
\hline \multicolumn{5}{|l|}{ Nausea } \\
\hline Yes & 91 & $14(15.4)$ & $1.1(0.6-2.2)$ & 0.733 \\
\hline No & 311 & $43(13.8)$ & Reference & \\
\hline \multicolumn{5}{|l|}{ Vomiting } \\
\hline Yes & 38 & $9(23.7)$ & $2.0(0.9-4.6)$ & 0.088 \\
\hline No & 364 & $48(13.2)$ & Reference & \\
\hline \multicolumn{5}{|l|}{ Abdominal pain } \\
\hline Yes & 132 & $23(17.4)$ & $1.5(0.8-2.6)$ & 0.223 \\
\hline No & 270 & $34(12.6)$ & Reference & \\
\hline
\end{tabular}

$N$ number examined, $n$ number infected with intestinal microsporidiosis, HIV human immunodeficiency virus, AIDS acquired immunodeficiency syndrome, $A R T$ antiretroviral therapy, NACP National AIDS Control Program, OR odds ratio, $\mathrm{Cl}$ confidence interval
Table 4 Predictors of intestinal microsporidiosis among HIV/ AIDS patients receiving ART in the clinic of NACP at Al-Jomhori Educational Hospital in Sana'a, Yemen (2019-2020)

\begin{tabular}{|c|c|c|c|c|}
\hline \multirow[t]{2}{*}{ Variable } & \multirow[t]{2}{*}{$N$} & \multicolumn{2}{|c|}{ Intestinal microsporidiosis } & \multirow[t]{2}{*}{$P$-value } \\
\hline & & $n(\%)$ & OR $(95 \% \mathrm{Cl})$ & \\
\hline \multicolumn{5}{|c|}{ CD4 cell count $(/ \mu \mathrm{l})$} \\
\hline$<200$ & 90 & $23(25.6)$ & $2.7(1.5-5.0)$ & \multirow[t]{2}{*}{0.001} \\
\hline$\geq 200$ & 306 & $34(11.1)$ & Reference & \\
\hline \multicolumn{5}{|c|}{ Source of drinking water } \\
\hline Bottled & 150 & $17(11.3)$ & Reference & \multirow[t]{2}{*}{0.238} \\
\hline Unbottled & 252 & $40(15.9)$ & $1.5(0.8-2.7)$ & \\
\hline \multicolumn{5}{|c|}{ Bathing and/or swimming outdoors } \\
\hline Yes & 93 & $12(12.9)$ & $0.9(0.4-1.7)$ & \multirow[t]{2}{*}{0.738} \\
\hline No & 309 & $45(14.6)$ & Reference & \\
\hline \multicolumn{5}{|c|}{ Contact with soil } \\
\hline Yes & 287 & $46(16.0)$ & $2.4(0.9-6.2)$ & \multirow[t]{2}{*}{0.083} \\
\hline No & 67 & $5(7.5)$ & Reference & \\
\hline \multicolumn{5}{|c|}{ Washing hands after contact with soil } \\
\hline Yes & 133 & $11(8.3)$ & Reference & \multirow[t]{2}{*}{0.002} \\
\hline No & 155 & $34(21.9)$ & $3.1(1.5-6.4)$ & \\
\hline \multicolumn{5}{|c|}{ Washing hands before eating } \\
\hline Yes & 307 & $30(9.8)$ & Reference & \multirow[t]{2}{*}{$<0.001$} \\
\hline No & 95 & $27(28.4)$ & $3.7(2.0-6.6)$ & \\
\hline \multicolumn{5}{|c|}{ Eating unwashed raw produce } \\
\hline Yes & 199 & $37(18.6)$ & $2.1(1.2-3.7)$ & \multirow[t]{2}{*}{0.015} \\
\hline No & 201 & $20(10.0)$ & Reference & \\
\hline \multicolumn{5}{|c|}{ Presence of domestic animals in the house } \\
\hline Yes & 178 & $22(12.4)$ & $0.8(0.4-1.4)$ & \multirow[t]{2}{*}{0.390} \\
\hline No & 224 & $35(15.6)$ & Reference & \\
\hline \multicolumn{5}{|c|}{ Presence of indoor latrines } \\
\hline Yes & 385 & $46(11.9)$ & Reference & \multirow[t]{2}{*}{$<0.001$} \\
\hline No & 17 & $11(64.7)$ & $13.5(4.8-38.3)$ & \\
\hline \multicolumn{5}{|c|}{ Indiscriminate defecation } \\
\hline Yes & 162 & $24(14.8)$ & $1.1(0.6-2.0)$ & \multirow[t]{2}{*}{0.877} \\
\hline No & 182 & $25(13.7)$ & Reference & \\
\hline
\end{tabular}

$N$ number examined, $n$ number infected with intestinal microsporidiosis, HIV human immunodeficiency virus, AIDS acquired immunodeficiency syndrome, $A R T$ antiretroviral therapy, NACP National AIDS Control Program, CD4 cluster of differentiation 4, $O R$ odds ratio, $\mathrm{Cl}$ confidence interval

intestinal microsporidiosis among HIV/AIDS patients (Table 5).

\section{Discussion}

To the best of our knowledge, this is the first study to report on the prevalence and predictors of intestinal microsporidiosis among HIV/AIDS patients in Yemen. It revealed the prevalence of intestinal microsporidiosis among $14.2 \%$ of HIV/AIDS patients receiving treatment at the ART clinic of the NACP in Sana'a city. The prevalence of intestinal microsporidiosis in the present study is 
Table 5 Independent predictors associated with intestinal microsporidiosis among HIV/AIDS patients receiving ART in the clinic of NACP at Al-Jomhori Educational Hospital in Sana'a, Yemen (2019-2020)

\begin{tabular}{llll}
\hline Variable & AOR & 95\% Cl & $P$-value \\
\hline Having <200 CD4 cells/ $\mu$ l & 3.2 & $1.5-6.9$ & 0.003 \\
Not washing hands after contact with soil & 2.5 & $1.1-5.4$ & 0.026 \\
Not washing hands before eating & 3.1 & $1.5-6.4$ & 0.003 \\
Eating unwashed raw produce & 2.5 & $1.2-5.3$ & 0.017 \\
Absence of indoor latrines & 6.2 & $1.5-25.9$ & 0.012 \\
\hline
\end{tabular}

HIV human immunodeficiency virus, AIDS acquired immunodeficiency syndrome, ART antiretroviral therapy, NACP National AIDS Control Program, CD4 cluster of differentiation $4, A O R$ adjusted odds ratio, $C /$ confidence interval

comparable to the pooled prevalence of $13.0 \%$ in Eastern Europe and Central Asia, 14.4\% in Western and Central Europe and North America and $15.4 \%$ in sub-Saharan Africa [25]. Compared to the present study, prevalence rates of 11.3-16.6\% among HIV/AIDS patients were reported from Mali, Venezuela, Addis Ababa of Ethiopia, Benin city of Nigeria, Chandigarh city of India and Burkina Faso (using microscopy), from Kerman city of Iran, Tunisia and Guangxi region of China (using PCR), Russia (using serological testing) and Argentina using TEM $[16,17,30-38]$. However, much lower prevalence rates of 0.8-8.5\% were reported among HIV/AIDS patients from the United States of America, France, Kinshasa city of the Democratic Republic of the Congo (using PCR), Shiraz city of Iran, Bamenda city of Cameroon, Lucknow city of India (using PCR), Malaysia, the Abeokuta and Niger states of Nigeria and Hunan province of China [39-48]. On the other hand, higher prevalence rates of 21.3-85.2\% were reported among HIV/AIDS patients from Uganda, Thailand, Lagos city of Nigeria, Buea and Limbe cities of Cameroon, Malawi (using PCR) and Mexico [49-54]. Variations in the prevalence of intestinal microsporidiosis could be attributed to differences in sociodemographic, environmental and behavioral risk factors. Besides, the use of different microscopical, immunological and molecular techniques plays a role in such variations. Therefore, the prevalence of intestinal microsporidiosis among HIV/AIDS patients in the present study should be compared and interpreted cautiously against the prevalence rates reported elsewhere.

The absence of a significant association between intestinal microsporidiosis and gender in the present study (18.0\% vs. $13.1 \%$ for females and males, respectively) is in agreement with the finding reported among HIVpositive patients from Chandigarh city of India [17] and HIV/AIDS patients from Guangxi region of China [36]. In contrast, a significant association between intestinal microsporidiosis and gender of HIV-infected patients was reported from the Democratic Republic of the Congo, Benin city of Nigeria and Lucknow city of India $[34,41,44]$. On the other hand, the absence of a significant association between intestinal microsporidiosis and age in the present study is in agreement with the findings reported among HIV-infected patients from India, China and France [17, 36, 55]. In the present study, residence and household size were not significant predictors of intestinal microsporidiosis among HIV/AIDS patients. In contrast, a significant association was found between living in slum or rural areas and intestinal microsporidiosis among HIV-infected patients from Zimbabwe and New Delhi city of India [56, 57].

The absence of a significant association between intestinal microsporidiosis and the literacy status of HIV/ AIDS patients in the present study is consistent with that reported among Chinese HIV/AIDS patients [36] and Nigerian HIV-infected patients [47]. Nevertheless, the absence of a significant association between intestinal microsporidiosis and the employment status of HIV/ AIDS patients in the present study is inconsistent with that reported among Chinese HIV/AIDS patients, where the prevalence of intestinal microsporidiosis was significantly higher among farmers [36].

Having $<200 \mathrm{CD} 4$ cells/ $\mu \mathrm{l}$ was a significant independent predictor of intestinal microsporidiosis among HIV/ AIDS patients in the present study, increasing the likelihood of infection by threefold. Therefore, physicians should consider microsporidiosis in HIV/AIDS patients with such low CD4 cell counts, particularly diarrheic patients. This finding agrees with that found among HIV/AIDS patients from the Democratic Republic of the Congo, Cameroon, Lucknow city of India, and the Abeokuta and Niger states of Nigeria [41, 44, 46, 47, 52]. In contrast, intestinal microsporidiosis was not significantly associated with CD4 cell counts among HIV/ AIDS patients from the Guangxi region of China [36]. Severe immunosuppression with below 200 CD4 cells/ $\mu \mathrm{l}$ increases the viral load that affects the immune system, posing patients to the risk of infection with microsporidia and other opportunistic pathogens [11]. The protective role of $\mathrm{T}$-cells against microsporidia has been well documented in animal models, where mice infected with microsporidia died of the disease but survived with T-cell transfers from sensitized donor mice [58].

Diarrhea was the only gastrointestinal feature significantly associated with intestinal microsporidiosis among HIV/AIDS patients in the present study, where patients with diarrhea were 3.4-fold more likely to have intestinal microsporidiosis. Similarly, intestinal microsporidiosis was significantly associated with diarrhea among HIV-infected patients from Lucknow city of India [44]. 
Intestinal microsporidiosis has therefore to be considered when investigating Yemeni HIV/AIDS patients for the causes of diarrhea, considering that routine stool examination does not include the detection of microsporidia. In contrast, intestinal microsporidiosis was not significantly associated with diarrhea among HIVinfected patients from Venezuela and the Abeokuta state of Nigeria [31, 46]. In another context, intestinal microsporidiosis could not be detected using PCR among HIVinfected patients with unexplained diarrhea in Denmark [59]. The absence of a significant association between intestinal microsporidiosis and nausea, vomiting or abdominal pain among HIV/AIDS patients in the present study is in line with that observed among HIV-infected patients from Thailand [50].

The source of drinking water was not significantly associated with the acquisition of intestinal microsporidiosis in the present study, showing that HIV/AIDS patients might be more exposed to spores from other sources such as contaminated soil. However, there is a need to assess the occurrence of microsporidian spores in different water sources. Likewise, the absence of such an association was found among HIV-infected patients from France and New Delhi city of India [55, 57]. In contrast, drinking unpiped or unfiltered water was found to be significantly associated with intestinal microsporidiosis among HIV-infected patients from Lucknow city of India and Zimbabwe [44, 56].

The present finding that bathing and/or swimming outdoors was not a significant predictor of intestinal microsporidiosis HIV/AIDS patients is inconsistent with the significant association between pool swimming and intestinal microsporidiosis reported among HIV-infected patients from France [55]. Nevertheless, the present study revealed that the likelihood of infection increased by three fold and four fold, respectively, among patients not washing hands after contact with soil and those eating without washing hands. It is noteworthy that microsporidia are ubiquitous, and their spores can survive and remain infective for up to 6 months in dry conditions [60]. Soil contaminated with spores can be a major source of infection transmission through unwashed hands after contact with soil and before eating. Therefore, hand hygiene with soap and water after contact with soil and before meals is an important practice to be delivered to HIV/AIDS patients as part of educational awarenessraising messages to reduce their exposure to many foodborne infections, including intestinal microsporidiosis.

The significant association between intestinal microsporidiosis and consuming unwashed raw produce among HIV/AIDS patients in Sana'a city is consistent with that reported among Peruvian HIV/AIDS patients consuming watermelon in Lima city [61]. Microsporidia are potentially transmitted via food-borne ingestion [62], and this could partially explain why those consuming unwashed raw produce in the present study were about twice and a half more likely to have intestinal microsporidiosis compared to their counterparts. In this context, microsporidian spores have been detected on fresh fruit and vegetables, and vegetables contaminated with spores have been associated with foodborne outbreaks elsewhere [63, 64]. HIV/AIDS patients should therefore be educated about the importance of proper washing of raw produce, such as fruit and vegetables, before eating.

Microsporidia are not host-specific, infecting a wide range of invertebrate and vertebrate animals. Nevertheless, the importance of zoonotic transmission is still not fully studied, particularly in developing countries. In the present study, the presence of domestic animals was not significantly associated with intestinal microsporidiosis among HIV/AIDS patients. Consistent findings were reported among HIV/AIDS patients from France and HIV-infected patients from Lucknow city of India and Nigeria $[44,47,55]$. In contrast, the presence of domestic animals was significantly associated with intestinal microsporidiosis among HIV/AIDS patients from Zimbabwe, Lima city of Peru, New Delhi city of India and the Democratic Republic of the Congo [56, 57, 61, 65]. However, the presence of domestic animals does not mean direct exposure or contact with them, and frequent occupational contact with animals can increase the risk of infection.

The absence of indoor latrines in the present study was a significant independent predictor of intestinal microsporidiosis, where the likelihood of infection was approximately sixfold higher among those having no latrines. This finding is consistent with that observed among HIV/ AIDS patients from Peru, where the lack of flush toilets in houses was significantly associated with $E$. bieneusi infection [61]. Likewise, the absence of indoor toilets and using public toilets were significantly associated with intestinal microsporidiosis among HIV-infected patients from New Delhi city of India [57]. In another context, using public and individual pit toilets was significantly associated with intestinal microsporidiosis among HIV/AIDS patients from the Democratic Republic of the Congo [65]. In contrast, the absence of latrines was not significantly associated with intestinal microsporidiosis among Nigerian HIV-infected patients [47]. Because most infections occur by human-to-human transmission through the fecal-oral route [62], the transmission of spores while using public toilets could occur through touching door handles, water taps, or using the containers that are kept in public toilets for cleaning purposes. It is noteworthy that Yemenis usually use water cups or containers instead of toilet paper for such purposes, exposing them to the 
risk of infection. Although indiscriminate defecation outdoors can contribute to indirect risk of infection, it was not significantly associated with intestinal microsporidiosis in the present study. In contrast, defecation in open fields was significantly associated with intestinal microsporidiosis among HIV-infected patients from New Delhi city of India [57]. Defecation in open fields could lead to contact with soil or exposure to recreational waters contaminated with spores from urine and stool of infected animals and humans [66].

The present study is limited by the use of light microscopy of stained smears for the detection of microsporidia, making their identification to the species level impossible. However, this study aimed to detect microsporidia rather than their speciation, and future molecular studies are required for the speciation and genotyping of microsporidia. This pioneer study uncovered the burden of intestinal microsporidiosis among HIV/AIDS patients in Sana'a. Another issue is that the prevalence of intestinal microsporidiosis could be higher than that found in the present study because of the lower specificity and sensitivity of light microscopy compared to molecular techniques [18]. Therefore, molecular studies are recommended to determine the prevalence of intestinal microsporidiosis among HIV/AIDS patients after controlling for the possible disadvantages of such techniques, such as the difficult extraction of spore nucleic acids and the presence of PCR inhibitors in stool samples. To reach as an accurate estimate of the prevalence of intestinal microsporidiosis as possible, the GCK staining technique was used for detecting microsporidian spores because of its high specificity and sensitivity levels compared to the chromotrope 2R-based WMT [24]. This technique is an improved modification of the quick-hot Gram-chromotrope technique [23], which was developed for rapid and good differentiation of microsporidian spores from the background fecal materials. From a diagnostic perspective, assessment of the GCK staining technique for the diagnosis of intestinal microsporidiosis needs to be evaluated compared to PCR among HIV/AIDS and other immunocompromized patients in resource-limited countries, including Yemen, where the cost and applicability of PCR are still impractical.

\section{Conclusions}

The prevalence of intestinal microsporidiosis among HIV/AIDS patients receiving ART in Sana'a is high and comparable to that reported from several other countries, being prevalent among approximately $14.0 \%$ of patients and significantly associated with diarrhea. Therefore, special requests for its investigation in diarrheic HIV/AIDS patients by clinicians are critical, considering the impracticality of routine stool examination in its diagnosis. Demographics, source of drinking water, bathing and/or swimming outdoors, contact with soil, presence of domestic animals in the house and indiscriminate defecation could not be of value in predicting the infection among HIV/AIDS patients. However, intestinal microsporidiosis could be predicted among patients who have $<200 \mathrm{CD} 4$ cells $/ \mu \mathrm{l}$, have poor hand hygiene after contacting soil and before eating, usually eat unwashed raw produce, or do not possess indoor latrines. Large-scale studies on the epidemiology and predictors of intestinal microsporidiosis among HIV/AIDS patients across the country are warranted, preferably with the adoption of molecular techniques.

\section{Abbreviations}

AIDS: Acquired immunodeficiency syndrome; AOR: Adjusted odds ratio; CD4: Cluster of differentiation 4; Cl: Confidence interval; EDTA: Ethylenediaminetetraacetic acid; ELISA: Enzyme-linked immunosorbent assay; GCK: Gramchromotrope Kinyoun; HIV: Human immunodeficiency virus; IQR: Interquartile range; NCAP: National AIDS Control Program; OR: Odds ratio; PCR: Polymerase chain reaction; SD: Standard deviation; SPSS: Statistical Package for the Social Sciences; TEM: Transmission electron microscopy; WMT: Weber's modified trichrome.

\section{Acknowledgements}

The authors thank Dr. Mohammed Abdullah Aldawla, Director of NACP at the Ministry of Public Health \& Population in Sana'a for his permission to perform this study. They also thank the administration and staff of the ART Clinic of the NACP at Al-Jomhori Educational Hospital in Sana'a city as well as Dr. Aisha Al-Moafa from the Department of Ophthalmology at Al-Jomhori Educational Hospital for their help and cooperation during data and sample collection. They are grateful to Dr. Mohammed Mahdy and Dr. Abdulsalam Al-Mekhlafi from the Department of Medical Parasitology, Faculty of Medicine and Health Sciences, Sana'a University, for their advice at the beginning of the work. They also thank Mr. Moath Al-Faqeeh from the Department of Medical Parasitology at the Faculty of Medicine and Health Sciences, Sana'a University, for his assistance during laboratory investigations. The authors express their great appreciation to all HIV/AIDS patients participating in this study.

\section{Authors' contributions}

KARA conceived the idea of the study and designed the study protocol. KARA collected data and samples and performed laboratory investigations. KARA and RA analyzed data and drafted the manuscript. RA and SAA supervised the work. All authors revised the final draft of the submitted manuscript. All authors read and approved the final manuscript.

Funding

Not applicable.

Availability of data and materials

Data are available within the manuscript and can be provided by the corresponding author.

\section{Declarations}

\section{Ethics approval and consent to participate}

The protocol of this study was approved by the Research Ethics Committee of the Faculty of Medicine and Health Sciences, Sana'a University, Yemen. Written informed consent was obtained from all participants after giving them a clear explanation of the objectives of the study and assuring the confidentiality of their data. 


\section{Consent for publication \\ Not applicable.}

\section{Competing interests}

The authors declare that they have no competing interests.

\section{Author details}

1 Department of Medical Parasitology, Faculty of Medicine and Health Sciences, Sana'a University, Sana'a, Yemen. ${ }^{2}$ Tropical Disease Research Center, Faculty of Medicine and Health Sciences, University, of Science and Technology, Sana'a, Yemen.

Received: 13 June 2021 Accepted: 21 December 2021

Published online: 04 January 2022

\section{References}

1. Han B, Weiss LM. Microsporidia: obligate intracellular pathogens within the fungal kingdom. Microbiol Spectr. 2017;5(2):10. https://doi.org/10. 1128/microbiolspec.FUNK-0018-2016.

2. Li W, Feng Y, Santin M. Host specificity of Enterocytozoon bieneusi and public health implications. Trends Parasitol. 2019;35(6):436-51. https:// doi.org/10.1016/j.pt.2019.04.004.

3. Weiss LM. Microsporidiosis. In: Hunter's tropical medicine and emerging infectious diseases. 10th ed. Amsterdam: Elsevier; 2020. p. 825-31.

4. Laksemi DA, Suwanti LT, Mufasirin M, Suastika K, Sudarmaja M. Opportunistic parasitic infections in patients with human immunodeficiency virus/acquired immunodeficiency syndrome: a review. Vet World. 2019;13(4):716-25. https://doi.org/10.14202/vetworld.2020.716-725.

5. Didier ES, Weiss LM. Microsporidiosis: not just in AIDS patients. Curr Opin Infect Dis. 2011;24(5):490-5. https://doi.org/10.1097/QCO.0b013e3283 4aa152.

6. Heyworth MF. Molecular diagnosis of human microsporidian infections. Trans R Soc Trop Med Hyg. 2017;111(9):382-3. https://doi.org/10.1093/ trstmh/trx070.

7. Didier ES. Microsporidiosis: an emerging and opportunistic infection in humans and animals. Acta Trop. 2005;94(1):61-76. https://doi.org/10. 1016/j.actatropica.2005.01.010

8. Fayer R, Santin-Duran M. Epidemiology of microsporidia in humans. In: Weiss L, Becnel JJ, editors. Microsporidia: pathogens of opportunity. Hoboken: Wiley; 2014. p. 135-64.

9. Zainudin NS, Nasarudin SNS, Periyasamy P, Moktar N, Noordin R, Osman E. Diagnosis of disseminated microsporidiosis: Detection of circulating Enterocytozoon bieneusi DNA in blood of HIV/AIDS patients. Trop Biomed. 2016:33(4):761-70.

10. Franzen C, Muller A. Microsporidiosis: human diseases and diagnosis. Microbes Infect. 2001;3(5):389-400. https://doi.org/10.1016/s12864579(01)01395-8.

11. Bharmal R, Tiwari R. HIV and AIDS: basic elements and priorities. Dordrecht: Springer; 2007.

12. World Health Organization. Global health observatory (GHO) data: HIV/ AIDS; 2018.

13. Abdulrazzak MH, Alsahybi AH, Assabri A, Khader Y. Evaluation of HIV reporting form in Sana'a city, Yemen, 2016. Inquiry. 2019;56:46958019847020. https://doi.org/10.1177/0046958019847020.

14. Degenhardt L, Charlson F, Stanaway J, Larney S, Alexander LT, Hickman $M$, et al. Estimating the burden of disease attributable to injecting drug use as a risk factor for HIV, hepatitis $C$, and hepatitis B: findings from the Global Burden of Disease Study 2013. Lancet Infect Dis. 2016;16(12):1385-98. https://doi.org/10.1016/S1473-3099(16)30325-5.

15. Regional Office for the Eastern Mediterranean/World Health Organization. Regional Office for the Eastern Mediterranean/World Health Organization. Yemen HIV country profile 2016 http://www.emro.who.int/ asd/country-activities/yemen-hiv-country-profile-2016.html. Accessed 27 May 2021.

16. Velasquez JN, di Risio C, Etchart C, Chertcoff AV, Astudillo OG, Carnevale S. Multimethodological approach to gastrointestinal microsporidiosis in HIV-infected patients. Acta Parasitol. 2019;64(3):658-69. https://doi.org/ 10.2478/s11686-019-00095-z.
17. Saigal K, Khurana S, Sharma A, Sehgal R, Malla N. Comparison of staining techniques and multiplex nested PCR for diagnosis of intestinal microsporidiosis. Diagn Microbiol Infect Dis. 2013;77(3):248-9. https://doi.org/ 10.1016/j.diagmicrobio.2013.07.004

18. Ghosh K, Weiss LM. Molecular diagnostic tests for microsporidia. Interdiscip Perspect Infect Dis. 2009;2009: 926521. https://doi.org/10.1155/2009/ 926521.

19. Weber R, Schwartz DA, Deplazes P. Laboratory diagnosis of microsporidiosis. In: The microsporidia and microsporidiosis. Washington: ASM Press; 1999. p. 315-62.

20. Weber R, Bryan RT, Owen RL, Wilcox CM, Gorelkin L, Visvesvara GS. Improved light-microscopical detection of microsporidia spores in stool and duodenal aspirates. The Enteric Opportunistic Infections Working Group. N Engl J Med. 1992;326(3):161-6. https://doi.org/10.1056/NEJM1 99201163260304

21. Weber R, Bryan RT. Microsporidial infections in immunodeficient and immunocompetent patients. Clin Infect Dis. 1994;19(3):517-21. https:// doi.org/10.1093/clinids/19.3.517.

22. Moura H, Schwartz DA, Bornay-Llinares F, Sodre FC. A new and improved" quick-hot Gram-chromotrope" technique that differentially stains microsporidian spores in clinical samples, including paraffin-embedded tissue sections. Arch Pathol Lab Med. 1997;121(8):888.

23. Moura H, Silva JLND, SodrÉ FC, Brasil P, Wallmo K, Wahlquist S, et al. GramChromotrope: a new technique that enhances detection of microsporidial spores in clinical samples. J Eukaryot Microbiol. 1996;43(5):94S-S95. https://doi.org/10.1111/j.1550-7408.1996.tb05019.x.

24. Salleh FM, Al-Mekhlafi AM, Nordin A, Yasin AM, Al-Mekhlafi HM, Moktar N. Evaluation of Gram-chromotrope Kinyoun staining technique: its effectiveness in detecting microsporidial spores in fecal specimens. Diagn Microbiol Infect Dis. 2011;69(1):82-5.

25. Wang ZD, Liu Q, Liu HH, Li S, Zhang L, Zhao Y-K, et al. Prevalence of Cryptosporidium, microsporidia and Isospora infection in HIV-infected people: a global systematic review and meta-analysis. Parasit Vectors. 2018;11(1):28. https://doi.org/10.1186/s13071-017-2558-x.

26. Cotte L, Rabodonirina M, Chapuis F, Bailly F, Bissuel F, Raynal C, et al. Waterborne outbreak of intestinal microsporidiosis in persons with and without human immunodeficiency virus infection. J Infect Dis. 1999;180(6):2003-8. https://doi.org/10.1086/315112.

27. Central Statistical Organization. Statistical Year Book: Population and Housing Census 2017 Sana'a: CSO; 2017.

28. World Health Organization. Diarrhoeal disease: key facts https://www. who.int/news-room/fact-sheets/detail/diarrhoeal-disease. Accessed 27 May 2021.

29. Kokoskin E, Gyorkos TW, Camus A, Cedilotte L, Purtill T, Ward B. Modified technique for efficient detection of microsporidia. J Clin Microbiol. 1994;32(4):1074-5. https://doi.org/10.1128/JCM.32.4.1074-1075.1994.

30. Cisse OA, Ouattara A, Thellier M, Accoceberry I, Biligui S, Minta D, et al Evaluation of an immunofluorescent-antibody test using monoclonal antibodies directed against Enterocytozoon bieneusi and Encephalitozoon intestinalis for diagnosis of intestinal microsporidiosis in Bamako (Mali). J Clin Microbiol. 2002;40(5):1715-8. https://doi.org/10.1128/JCM.40.5.17151718.2002

31. Chacin-Bonilla L, Panunzio AP, Monsalve-Castillo FM, Parra-Cepeda IE, Martinez R. Microsporidiosis in Venezuela: prevalence of intestinal microsporidiosis and its contribution to diarrhea in a group of human immunodeficiency virus-infected patients from Zulia State. Am J Trop Med Hyg. 2006;74(3):482-6.

32. Endeshaw T, Kebede A, Verweij JJ, Zewide A, Tsige K, Abraham Y, et al. Intestinal microsporidiosis in diarrheal patients infected with human immunodeficiency virus-1 in Addis Ababa, Ethiopia. Jpn J Infect Dis. 2006;59(5):306-10.

33. Kucerova Z, Sokolova O, Demyanov A, Kvac M, Sak B, Kvetonova D, et al. Microsporidiosis and cryptosporidiosis in HIV/AIDS patients in St. Petersburg, Russia: serological identification of microsporidia and Cryptosporidium parvum in sera samples from HIV/AIDS patients. AIDS Res Hum Retroviruses. 2011;27(1):13-5. https://doi.org/10.1089/aid.2010.0132.

34. Akinbo FO, Okaka CE, Omoregie R, Dearen T, Leon ET, Xiao L. Molecular epidemiologic characterization of Enterocytozoon bieneusi in HIV-infected persons in Benin city, Nigeria. Am J Trop Med Hyg. 2012;86(3):441-5. https://doi.org/10.4269/ajtmh.2012.11-0548. 
35. Aissa S, Chabchoub N, Abdelmalek R, Kanoun F, Goubantini A, Ammari $L$, et al. Asymptomatic intestinal carriage of microsporidia in HIV-positive patients in Tunisia: prevalence, species, and pathogenesis. Med Sante Trop. 2017;27(3):281-5. https://doi.org/10.1684/mst.2017.0697.

36. Liu H, Jiang Z, Yuan Z, Yin J, Wang Z, Yu B, et al. Infection by and genotype characteristics of Enterocytozoon bieneusi in HIV/AIDS patients from Guangxi Zhuang autonomous region, China. BMC Infect Dis. 2017;17(1):1-8. https://doi.org/10.1186/s12879-017-2787-9.

37. Nooshadokht M, Sharifi I, Mohammadi MA, Pirestani M, Afgar A, Mahootchi A, et al. Intestinal microsporidiosis in Iran: infection in immune-compromised and immunocompetent patients. Curr Med Mycol. 2017;3(1):30. https://doi.org/10.18869/acadpub.cmm.3.1.30.

38. Yacouba A, Sawadogo MP, Diallo I, Sangare I, Bamba S, Ouattara B, et al. Opportunistic and other intestinal parasites infections among HIVpositive patients in the era of combination antiretroviral therapy and preventive treatment in Ouagadougou, Burkina Faso. J HIV Clin Sci Res. 2017;4(1):008-14.

39. Dworkin MS, Buskin SE, Davidson AJ, Cohn DL, Morse A, Inungu J, et al. Prevalence of intestinal microsporidiosis in human immunodeficiency virus-infected patients with diarrhea in major United States cities. Rev Inst Med Trop Sao Paulo. 2007;49(6):339-42. https://doi.org/10.1590/s003646652007000600001.

40. Lagrange-Xélot M, Porcher R, Sarfati C, De Castro N, Carel O, Magnier JD, et al. Isosporiasis in patients with HIV infection in the highly active antiretroviral therapy era in France. HIV Med. 2008;9(2):126-30. https://doi.org/ 10.1111/j.1468-1293.2007.00530.x.

41. Wumba R, Jean M, Benjamin L-M, Madone M, Fabien K, Josué Z, et al. Enterocytozoon bieneusi identification using real-time polymerase chain reaction and restriction fragment length polymorphism in HIV-infected humans from Kinshasa province of the Democratic Republic of Congo. J Parasitol Res. 2012. https://doi.org/10.1155/2012/278028.

42. Agholi M, Hatam GR, Motazedian MH. HIV/AIDS-associated opportunistic protozoal diarrhea. AIDS Res Hum Retroviruses. 2013;29(1):35-41. https:// doi.org/10.1089/AID.2012.0119.

43. Bissong M, Nguemain N, Ng'awono T, Kamga F. Burden of intestinal parasites amongst HIV/AIDS patients attending Bamenda Regional Hospital in Cameroon. Afr J Clin Exper Microbiol. 2015;16(3):97-103. https://doi.org/ 10.4314/ajcem.v16i3.3.

44. Khanduja S, Ghoshal U, Agarwal V, Pant P, Ghoshal UC. Identification and genotyping of Enterocytozoon bieneusi among human immunodeficiency virus infected patients. J Infect Public Health. 2017;10(1):31-40. https:// doi.org/10.1016/j.jiph.2016.01.005.

45. Zainudin NS, Nasarudin SNSA, Moktar N, Azil AH, Osman E. Human microsporidiosis in Malaysia: review of literatures. Malays J Pub Health Med. 2017;17(2):9-18.

46. Amoo JK, Akindele AA, Amoo AOJ, Efunshile AM, Ojurongbe TA, Fayemiwo SA, et al. Prevalence of enteric parasitic infections among people living with HIV in Abeokuta, Nigeria. Pan Afr Med J. 2018. https://doi.org/ 10.11604/pamj.2018.30.66.13160.

47. Ubanwa E, Omalu I, Olayemi I, Ejima I, Njoku M. Epidemiology of microsporidia infection among apparently healthy subject and immunocompromised patients in Minna. J Biosci Biotechnol Discov. 2019;4(2):36-42. https://doi.org/10.31248/JBBD2018.076.

48. Qiu L, Xia W, Li W, Ping J, Ding S, Liu H. The prevalence of microsporidia in China: a systematic review and meta-analysis. Sci Rep. 2019;9(1):3174. https://doi.org/10.1038/s41598-019-39290-3.

49. Tumwine JK, Kekitiinwa A, Bakeera-Kitaka S, Ndeezi G, Downing R, Feng $X$, et al. Cryptosporidiosis and microsporidiosis in Ugandan children with persistent diarrhea with and without concurrent infection with the human immunodeficiency virus. Am J Trop Med Hyg. 2005;73(5):921-5.

50. Viriyavejakul P, Nintasen R, Punsawad C, Chaisri U, Punpoowong B, Riganti M. High prevalence of Microsporidium infection in HIV-infected patients. Southeast Asian J Trop Med Public Health. 2009;40(2):223.

51. Ojuromi OT, Izquierdo F, Fenoy S, Fagbenro-Beyioku A, Oyibo W, Akanmu $A$, et al. Identification and characterization of microsporidia from fecal samples of HIV-positive patients from Lagos, Nigeria. PLoS ONE. 2012;7(4): e35239. https://doi.org/10.1371/journal.pone.0035239.

52. Nsagha DS, Njunda AL, Assob NJC, Ayima CW, Tanue EA, Kwenti TE. Intestinal parasitic infections in relation to CD4+ T cell counts and diarrhea in HIV/AIDS patients with or without antiretroviral therapy in
Cameroon. BMC Infect Dis. 2015;16(1):1-10. https://doi.org/10.1186/ s12879-016-1337-1.

53. Huibers MH, Moons P, Maseko N, Gushu MB, Iwajomo OH, Heyderman RS, et al. Multiplex real-time PCR detection of intestinal protozoa in HIV-infected children in Malawi, Enterocytozoon bieneusi is common and associated with gastrointestinal complaints and may delay BMI (nutritional status) recovery. Pediatr Infect Dis J. 2018;37(9):910. https://doi.org/ 10.1097/INF.0000000000001924.

54. Rodríguez-Pérez EG, Arce-Mendoza AY, Montes-Zapata Él, Limón A, Rodríguez LÉ, Escandón-Vargas K. Opportunistic intestinal parasites in immunocompromised patients from a tertiary hospital in Monterrey. Mexico Infez Med. 2019;27:168-74.

55. Hutin YJ, Sombardier M-N, Liguory O, Sarfati C, Derouin F, Modaï J et al. Risk factors for intestinal microsporidiosis in patients with human immunodeficiency virus infection: a case-control study. J Infect Dis. 1998;178(3):904-7. https://doi.org/10.1086/515353.

56. Gumbo T, Sarbah S, Gangaidzo IT, Ortega Y, Sterling CR, Carville A, et al. Intestinal parasites in patients with diarrhea and human immunodeficiency virus infection in Zimbabwe. AIDS. 1999;13(7):819-21. https://doi. org/10.1097/00002030-199905070-00011.

57. Dwivedi KK, Prasad G, Saini S, Mahajan S, Lal S, Baveja UK. Enteric opportunistic parasites among HIV infected individuals: associated risk factors and immune status. Jpn J Infect Dis. 2007;60(2/3):76.

58. Weber R, Bryan RT, Schwartz DA, Owen RL. Human microsporidial infections. Clin Microbiol Rev. 1994;7(4):426-61. https://doi.org/10.1128/ CMR.7.4.426.

59. Stensvold CR, Nielsen SD, Badsberg JH, Engberg J, Friis-Møller N, Nielsen SS, et al. The prevalence and clinical significance of intestinal parasites in HIV-infected patients in Denmark. Scand J Infect Dis. 2011;43(2):129-35. https://doi.org/10.3109/00365548.2010.524659.

60. Meyers WM, Firpo A, Wear DJ. Topics on the pathology of protozoan and invasive arthropod diseases. Washington, DC; 2011.

61. Bern C, Kawai V, Vargas D, Rabke-Verani J, Williamson J, Chavez-Valdez R, et al. The epidemiology of intestinal microsporidiosis in patients with HIV/ AIDS in Lima. Peru J Infect Dis. 2005;191(10):1658-64. https://doi.org/10. 1086/429674

62. Didier ES, Stovall ME, Green LC, Brindley PJ, Sestak K, Didier PJ. Epidemiology of microsporidiosis: sources and modes of transmission. Vet Parasitol. 2004;126(1-2):145-66. https://doi.org/10.1016/j.vetpar.2004.09.006.

63. Calvo M, Carazo M, Arias ML, Chaves C, Monge R, Chinchilla M. Prevalence of Cyclospora sp., Cryptosporidium sp, microsporidia and fecal coliform determination in fresh fruit and vegetables consumed in Costa Rica. Arch Latinoam Nutr. 2004;54(4):428-32.

64. Decraene V, Lebbad M, Botero-Kleiven S, Gustavsson A-M, Löfdahl M. First reported foodborne outbreak associated with microsporidia, Sweden, October 2009. Epidemiol Infect. 2012;140(3):519-27. https://doi.org/10. 1017/S095026881100077X

65. Wumba R, Longo-Mbenza B, Menotti J, Mandina M, Kintoki F, Situakibanza NH, et al. Epidemiology, clinical, immune, and molecular profiles of microsporidiosis and cryptosporidiosis among HIV/AIDS patients. Int J Gen Med. 2012;5:603. https://doi.org/10.2147/IJGM.S32344.

66. Hu Y, Feng Y, Huang C, Xiao L. Occurrence, source, and human infection potential of Cryptosporidium and Enterocytozoon bieneusi in drinking source water in Shanghai, China, during a pig carcass disposal incident. Environ Sci Technol. 2014;48(24):14219-27. https://doi.org/10.1021/es504 $464 t$

\section{Publisher's Note}

Springer Nature remains neutral with regard to jurisdictional claims in published maps and institutional affiliations. 